\title{
Carctol: Profit before Patients?
}

\author{
Edzard Ernst \\ Complementary Medicine, Peninsula Medical School, Universities of Exeter and Plymouth, Exeter, UK
}

\section{Key Words}

Carctol - Cancer

\section{Summary}

Background: Carctol is a herbal remedy that recently was widely reported to offer a cure for a range of cancers. This article is aimed at evaluating the evidence that supports this claim. Methods: In addition to numerous websites, we conducted systematic searches in six electronic databases. Any factual information relating to Carctol was considered. Results: The websites provided the composition of the herbal mixture and numerous claims as to its effectiveness. However, not a single scientific study of any style was found. Conclusions: The claim that Carctol is of any benefit to cancer patients is not supported by scientific evidence.

Every decade seems to have its own bogus 'alternative' cancer cure: Previously, we have encountered the Gerson diet, laetril, Essiac, mistletoe, shark cartilage - and now Carctol.

Carctol is a herbal mixture designed by Dr. Nandlal Tiwari, an Ayurvedic practitioner from India who has been promoting his remedy for about 20 years as a treatment of a wide range of conditions. Recently, Carctol has hit the headlines in Europe as an 'alternative' cancer cure. The claim is that it cures all cancers including breast cancer and that 'it may also be taken for the treatment of cancer where the limits of conventional medicine have been reached' [1].

\section{Schlüsselwörter \\ Carctol · Krebs}

\section{Zusammenfassung}

Hintergrund: Carctol ist ein pflanzliches Heilmittel, von dem in der letzten Zeit oft berichtet wurde, dass es zur Heilung verschiedener Krebsarten führen kann. Dieser Artikel soll die Beweise für diese Behauptung evaluieren. Methoden: Zusätzlich zu zahlreichen Webseiten haben wir sechs elektronische Datenbanken systematisch durchsucht. Jede faktische Information, die sich auf Carctol bezog, wurde erwogen. Ergebnisse: Die Webseiten lieferten Informationen zur Zusammensetzung der pflanzlichen Mixtur und zahlreiche Behauptungen bezüglich ihres Effekts. Jedoch konnte keine einzige wissenschaftliche Studie jedweder Art gefunden werden. Schlussfolgerungen: Die Behauptung, dass Carctol in irgendeiner Weise zum Wohlbefinden von Krebspatienten beiträgt, wird nicht durch wissenschaftliche Beweise gestützt.

\section{Composition}

According to Carctol's 'official website' [1] one 560-mg capsule of Carctol contains Hemidesmus indicus (roots): $20 \mathrm{mg} /$ Tribulus terrestris (seeds): $20 \mathrm{mg} /$ Piper cubeba Linn. (seeds): $120 \mathrm{mg} /$ Ammani vesicatoria (plant): $20 \mathrm{mg} /$ Lepidium sativum Linn. (seeds): $20 \mathrm{mg} /$ Blepharis edulis (seeds): $200 \mathrm{mg} /$ Smilax china Linn. (roots): $80 \mathrm{mg} /$ Rheumemodi wall (roots): $20 \mathrm{mg}$.

\begin{tabular}{ll}
\hline KARGER & $\oplus$ 2009 S. Karger GmbH, Freiburg \\
Fax +49 761 4520714 & Accessible online at: \\
Information@Karger.de & www.karger.com/brc \\
www.karger.com &
\end{tabular}




\section{Clinical Evidence}

Electronic literature searches were conducted (November 2008) in the following databases: Amed, Embase, Medline, Psychinfo, British Nursing Index, Herb of Science. The key word used was Carctol. No language or time restrictions were imposed.

No evidence emerged to show or to suggest that Carctol helps cancer patients in any way. In fact, I was unable to find a single article on Carctol in the medical literature. Some websites, e.g. [1], refer to scientific investigations, but on closer inspection these turn out to be either studies of chemical ingredients in the mixture or surveys of patients who used Carctol. Survey data are, of course, always inconclusive as to the clinical effectiveness of a medical intervention. The surveys on Carctol are more than inconclusive: They were not published in peer-reviewed journals and fail to provide even the most basic information required for even the most basic assessments of their validity. In addition, the web is full with testimonials about Carctol. Again, such reports do not provide any basis for conclusions about the effectiveness of the treatment.

\section{Postulated Mechanism of Action}

Dr. Tiwari seems to think that Carctol depletes the body of acidity [1]. This, he claims, creates an alkaline environment which kills cancer cells. Carctol is claimed to act slowly, and a 'two-month trial is the minimum essential period, but more normally a six month period is recommended with follow up periods' [2]. The theory that supposedly underpins Carctol is both implausible and unproven.

\section{Proponents}

In the UK, Dr. Rosy Daniel is the foremost promoter of Carctol. Dr. Daniel is the medical director of 'Health Creation', a Bath-based organisation. Its website states that it 'provides support and guidance for those who' ... choose not to have orthodox treatments' [3]. Dr. Daniel has 'specialised in the treatment of cancer with the herbal medicine carctol and salvestrol and has had some notable success with carctol since introducing its use to Great Britain in 2000' [3]. She has claimed that Carctol can 'make tumours disappear' [4].

\section{Marketing}

British law does not allow Carctol to be advertised. So, Dr. Daniel turned to a public relations (PR) company. Together they created a highly effective marketing campaign resulting in full-page newspaper articles and other promotion [4]. The PR company issued a press release that spoke of the 'walking miracles' and 'five extraordinary cases [that] have stunned the medical world' [4]. One of the largest British newspapers published a full-page feature on Dr. Daniel's 'discovery' with the title 'Since I have been putting people on Carctol I have seen miracles' [5]. In it Dr. Daniel stated that 'for the first time in 20 years I have a medicine that I believe will make a difference' [5]. As a result, there are now 14,200 websites on Carctol (Google search on 29/10/2008).

\section{The Claims}

A plethora of Carctol promotional sites claim that $30-40 \%$ of all patients will respond to Carctol. These sites fail to define what they mean by the term 'respond' and they also do not provide any scientific evidence to back up this claim.

\section{Other Treatments}

Most of the promotional literature points out that Carctol should be taken alongside conventional cancer treatments. But some statements also seem to encourage its use as an alternative therapy (see above).

In addition to taking Carctol, patients are advised to

- avoid acid food,

- follow a vegetarian diet,

- drink up to 51 of boiled water per day,

- avoid alcohol,

- avoid fried foods,

- avoid saturated fats.

\section{Cost}

Several sites offer Carctol for sale via mail order. The prices range from $£ 45$ to $£ 90$ for 1 month's supply. Postage and VAT come extra.

\section{Comment}

Carctol and the media hype surrounding it must have given many cancer patients hope. The question is whether this is a good or a bad thing. On the one hand, all good clinicians should inspire their patients with hope [6]. On the other hand, giving hope on false pretences is cruel and unethical.

Rosy Daniel rightly points out that all science begins with observations [5]. But all science then swiftly moves on and tests hypotheses. In the case of Carctol, over 20 years of experience in India and almost one decade of experience in the UK should be ample time to do this. Yet, we still have no data. Even the apparently spectacular cases observed by Dr. Daniel have not been published in the medical literature. 
Why is that so? I have to admit that I do not know the answer and therefore can only speculate. Perhaps, the clinicians who made the initially encouraging observations had no time to publish them, or they were unable to confirm them with subsequent research, or they did not bother to look further. Whatever the truth, it seems unethical to first make public statements that raise hopes and then not to provide the evidence [7].

The best and (some would say 'only') most responsible way to proceed, not just in the case of oncology but in any field of healthcare, I think, is to first provide the evidence and then to issue public claims. This may be far less profitable but it is, as far as I can see, the only way to prevent exploitation of vulnerable patients.

\section{Acknowledgement}

I am grateful to Kate Boddy for conducting the electronic literature searches.

\section{References}

1 Anonymous: Carctol official website. www carctolhome.com, 2008 [accessed 29/10/08]

2 Anonymous: Carctol. www.canceractive.com/page. php? $n=534,2008$ [accessed 29/10/08].

3 Health Creation: Dr. Rosy Daniel BSc MBBCh. www.healthcreation.co.uk/drrosydaniel, 2008 [accessed 23/10/08].
Marks N: PR coup for herbal cancer drug. BMJ 2004; 329:804.

5 Hall C: I've seen herbal remedy make tumours disappear, says respected cancer doctor. The Telegraph 2004;20 Sep.
6 Baum M: Concepts of holism in orthodox and alternative medicine; in Ernst E (ed): Healing, hype or harm? Exeter, Imprint Academia, 2008, 144-151.

7 Baum M, Ernst E: Ethics and complementary or alternative medicine; in Ernst E (ed): Healing, hype or harm? Exeter, Imprint Academia, 2008, 104-111. 